\title{
From the imperial to the empty calorie: how nutrition relations underpin food regime transitions
}

\author{
Jane Dixon
}

Accepted: 8 May 2009

(C) Springer Science+Business Media B.V. 2009

\begin{abstract}
This article works in a recursive manner by using the tools of a food regime approach to reinterpret the nutrition transition that has been underway internationally for 100 years, and then describing the contributions of nutrition science to the 1st and 2nd Food Regimes and the passages between Food Regimes. The resulting historyfrom the 'imperial calorie' through the 'protective' vitamin to the 'empty calorie'-illuminates a neglected dimension to food regime theorising: the role of socio-technical systems in shaping a set of value relations that are central to class relations. Contestation over one such system, nutritionalisation, currently involves an ungovernable array of actors. In describing the protagonists to the system of nutritionalisation, a classic confrontation emerges between technical and lifeworld rationality. Representing the former approach are actor networks responsible for the 'trade-inhealth' sector which produces foods and nutritional values aimed at both over-nourished and under-nourished populations. Clinging to a lifeworld rationality are culture eaters' worldwide, for whom nutrition value relations are secondary to communal and ecological relations. This dynamic appears within wealthier Asian states which are emerging as central to the trade-in-nutritional health sector while acting to protect their own customary dietary practices.
\end{abstract}

Keywords Food regimes - Nutrition transition · Public health $\cdot$ Socio-technical systems

\footnotetext{
J. Dixon $(\square)$

National Centre for Epidemiology and Population Health, Australian National University, Building 62, Mills Road, Acton, ACT 0200, Australia

e-mail: jane.dixon@anu.edu.au
}

\section{Introduction}

This article identifies a largely neglected socio-technical process, nutritrionalisation, which has been central to the spatial and temporal expansion, consolidation and crisisprone nature of the global industrial agri-food system and attendant capitalist formations. The nutritionalisation of modern food systems is a process that builds on a science devoted as Coveney (2006) puts it to the 'study of the metabolic fate of food', which he claims is 'part of a range of knowledges, strategies, and calculations with one major aim: a will to govern' (p. 23). Nutritionalisation involves three sub-processes: the enumeration, enrichment and promotion of both single foods and national food supplies in terms of a nutrient values profile (amounts and types of energy, protein, fats etc.).

Twenty years ago Friedmann and McMichael (1989) described the symbiosis between capitalism and food relations in terms of food regimes. Whilst their work recognised the stabilising force of class based diets and the destabilising potential of food insecurity, the role of science in adding particular value relations to food relations has not thus far been a feature of food regime theorising.

Inspired by a food regime approach, the article recasts the nutrition transition that has been underway internationally for over a century to be the outcome of a particular socio-technical system that has mobilised the material and symbolic values of nutrition with 'a will to govern'. This exercise in turn highlights the systematic deployment of nutritional values to secure the four pillars underlying the co-evolution of capitalism and food systems, or food regimes: trade/aid relationships, geo-political expansion, global labour force productivity gains and harmony, and product differentiation strategies (Friedmann and McMichael 1989). 
How the process of nutritionalisation has unfolded is clarified in following sections; but in summary it involves the co-option of nutrition science to extract surplus value and authority relations from food, and is most transparent when corporate strategies and public policies are framed in terms of nutritional disease and health and wealth advancement. Less obvious is how nutritional values have underpinned class-based advice on family functioning and daily life routines more generally. It was through nutrition values as well as wage values that social class relations were reproduced and struggled against, and I argue that this situation continues.

The article however also proposes that recent awareness of diet-related health inequities and the environmental externalities generated by a nutritionalised food system has been contributing to a crisis of legitimacy for the major proponents of such a system. The proponents include: agrifood corporations which use nutrition claims to differentiate their commodities; governments searching for a health system response to diet-related diseases; and the nutrition science and technology complexes responsible for both magnifying nutritional risks and marketing their industrial solutions. The present food and nutrition crisis is not solely about rising food prices and food scarcity but also concerns the health and culture-depleting nature of the 2nd Food Regime, and its key protagonists' attempts to construct a successor regime based on industrial principles.

\section{The twentieth century nutrition transition becomes a nutrition crisis}

Within the public health and development fields, the phrase 'the nutrition transition' recurs whenever links between newly affluent populations and dietary changes are being discussed. Specifically, the transition's twentieth century manifestation involves a shift away from plant-based diets towards higher per capita consumption of animal-based foods, oils and fats, processed sugars and processed carbohydrates (Popkin 1999). Among OECD countries, and increasingly among middle income countries, national food supplies are characterised by greater dietary diversity and dietary energy which together have delivered enhanced food security, although not to citizens living in poverty for considerable periods.

Due to its associations with both national economic development and improved population health status, the nutrition transition has been largely celebrated as a positive social and economic development. Economists (Fogel 2004; Steckel 2001) and The World Bank (2006) have explained the early twentieth century population explosion, population health gains and economic development 'success' of nations in terms of advances in agriculture and widespread access to 'good nutrition', particularly for mothers and infants. This argument has become public health and public policy orthodoxy (McKeown 1979; Porter 1999).

The modern nutrition transition which the 'West' experienced last century is more accurately described as consisting of two phases. The first, lasting about 60 years, involved the increase in dietary diversity, meat and lightly processed products. Hawkes (2006) describes the second phase in terms of food supply convergence and divergence, where poorer populations share diets restricted to relatively cheap, highly processed, high calorie foods and affluent populations enjoy dietary diversity including increasingly expensive fruits and vegetables. The urban centres of several middle-income Asian countries including Thailand, China and India have undergone phases one and two of the transition in the quick succession of 40 years (Popkin 2003).

Arguments about the nutrition-led economic miracle played a key role in shaping the early policies of the FAO as well as providing a raison d'etre for numerous international aid and charity organisations. However in the last decade, medical researchers have been raising alarm about what they are calling the 'diseases of affluence' or 'diseases of comfort' related to inferior diets and insufficient physical activity. For the first time in half a century, life expectancy in the US is predicted to fall as a result of individuals living for many years with the complications from obesity and diabetes; and there is evidence that almost half of the global burden of disease and more than half of all annual deaths are related to diet-related diseases (WHO 2002). In 2004, this statistic prompted the WHO and FAO to issue a joint global strategy urging governments to regulate and monitor levels of salt, sugar and fat in their food supplies (WHO/FAO 2004)_prompting a backlash against the agencies from the sugar and meat industries in the US and Australia.

The second phase of the nutrition transition is better described as a nutrition crisis, given that more than one third of the world's adult population is either under or overnourished. The crisis has escalated in the last quarter century due to interactions between unhealthy diets and disrupted agro-ecologies leading to lower plant-based yields. While ecologists are at an early stage of understanding the environmental impacts posed by demand for different diets there is general acceptance that:

- affluent country diets-high in red meat, oils, dairy, and pre-prepared foods and drinks — are neither sustainable in environmental nor health terms (Elinder 2005; McMichael et al. 2007; Mendez and Popkin 2004).

- even though human ancestors were meat eaters, they did not consume large volumes of processed animal products, including dairy. The global expansion of dairy industries is significantly increasing greenhouse 
gas emissions and land degradation caused by grazing ruminant animals (OECD 2008; Steinfeld et al. 2006).

- the most energy intensive food commodities are also the most health damaging (Carlsson-Kanyama et al. 2003; Oresund Food Network and Oresund Environment Academy 2008).

Another aspect to the crisis has been the steady corrosion of state sponsored and communal forms of food sovereignty. Governments are increasingly subservient to pannational food system bodies like Codex Alimentarius (McMichael 1996; Weis 2007), while local firms are captured by the finance capital of 'health and wellness' corporations such as Nestle (Burch and Lawrence in press). Communities and individuals are subject to 'Food from Nowhere' forms of gastro-anomie.

By using the tools of food regime theory-crisis and transition, geo-political dynamics, capital-state relations and producer-consumer relations-it is possible to discern the constituent elements of nutrition science complexes. They are comprised of temporally and spatially specific laboratories; observation and enumeration technologies; corporate and government sponsors; and a professional corps adept at enrolling discursive devices to manage producer-consumer relations through creating the 'nutricentric' citizen.

The rise of the nutricentric citizen

Up until the 1950s, the dominant system regulating the quantity and quality of the food supply and the way in which particular foods were distributed and incorporated into social life was centred in civil society and involved cuisine-the intergenerational sharing of food knowledge, preferred ingredients and cooking skills. However, cooking has been made redundant by the rise of commercial food providers, and with its passage so too is the role of cuisine for guiding food's incorporation within social life (Ulijaszek 2002).

Replacing this social regulatory system is a form of private regulation based on science and technology. Phrases such as 'nutritionism' (Belasco 1993), 'nutritionalisation' (Dixon 2002), 'nutrification' and 'nutrition terrorism' (Levenstein 1993), are used to capture a single argument: diets are being promoted on the sole criterion of their nutritional qualities. Scrinis (2007) has described the modern eating citizen as a nutricentric person, although this does not necessarily mean a healthy person (Rozin 2005). The nutricentric person's life is ruled by biomarkers: 'good' and 'bad' cholesterol, blood sugar levels, the GI (Glycemic Index), daily energy requirements (measured in kilojoules of calories), BMI (body mass index), and the HWR (hip waist ratio) (Scrinis 2007).
The paradox of an increased focus on nutrition values, at a time when the food supply is increasingly distanced physically and metaphysically, has only served to heighten public anxiety and food-related ontological insecurity (Fischler 1993; Levenstein 1993; Nestle 2002). Betsy Lerner's Food and Loathing: A Life Lived Out in Calories is a particularly evocative portrayal of how the social and ecological rupture between foods and eating is being embodied. Lerner, a member of Overeater's Anonymous (OA) in the US, uses her memoir to describe lifelong battles with overeating and mental illness. Originally appearing with the sub-title 'A Lament', she talks about being addicted to eating but in close to 300 pages rarely canvasses what foods she is eating (Adams 2007). This it seems is in keeping with an OA principle that forbids talk of 'actual food'.

The multiplying roles played by food beyond its role as a vehicle for nutrients-like the anchor for rituals, the herald of seasons-is dissipating. Discussing early twentieth century US government sponsored advice to housewives, Mudry argues that:

enumerated food [calories and price] made gastronomic knowledge impersonal, and devoid of any social, cultural, or geographic influences. The definition of reason and rationality shifted the discourse of food and eating from taste and experience to calculation and equation. The shift still resonates with us today. (Mudry 2006, p. 64)

Through nutricentrism, eating has become a personal project of endless self-improvement rather than part of a timeless social institution (Coveney 2006); and it is used as evidence of ethical personhood (Guthman and DuPuis 2006). The ancient dietetic philosophy that provided rules to guide the achievement of pleasure through eating has been supplanted by government dietary guidelines, and the application of corporate nutrition labels and dietary health claims. By fostering the nutricentric citizen, nutrition science complexes have aided and abetted agri-food commodity complexes.

In what follows, I deploy a food regime approach to describe how the nutrition crisis is complicating stateagribusiness and retail firm-consumer relationships as the various actors respond to food insecurity, diet-related diseases and food system governance realignments. Nutrition politics emerges as a key contributor to past, present and future food value relations.

\section{Food regimes are nutritional regimes}

Friedmann and McMichael (1989) have long recognised the symbiotic relationship between the class basis of diets 
and the 1st and 2nd Food Regimes. They described how under the 1st Food Regime, dietary staples (principally wheat and meat) were transferred from settler states to provide low cost wage foods in the rapidly industrialising colonial states. With an increase in volume and affordability of agricultural products after the Second World War, and food surpluses in the US, competition began with the rapidly expanding volume of processed foods. Under the 2nd Food Regime, finite biological capacity for calories constrained market growth (Leopold 1985). Foods were being designed with use values beyond satiety. The strategy of extending the market through differentiation within product lines by value adding nutrition is now well documented (Dixon and Banwell 2004; Heasman and Mellentin 2001; Scrinis 2008).

Friedmann and McMichael proposed that periods of food system stability coincided with a relatively smooth process of social reproduction: whether feeding labour forces of newly industrialising states, or weaning women away from the labour-intensive duty of family cooking so that they could augment industrial and service sector labour forces. What is understated in their account is the role played by nutrition science from the 1880s onwards in both the process of social class reproduction and in fostering the 1st and 2nd Food Regimes. Indeed, echoing food regime theorising, a leading nutrition scientist has observed that with the mid-nineteenth century establishment of a separate paramedical profession, dietetics, nutrition science 'became less a philosophy of life, more an instrument of state' (Cannon 2005, p. 702). In this vein, we now know that vitamin-fortified processed cereal and milk products acted as highly portable cultural economy nation-building vehicles, and their universalizing logic 'guided AngloAmerican efforts to construct a world food order' (Cullather 2007a, p. 40).

What follows are several cross-Atlantic examples of nutrition science based complexes which have played instrumental roles in the ordering and disordering of global food systems. Informed by a food regime approach, the account provides the basis for key insights into nutrition politics, and in turn the social history of nutrition politics reveals that food regimes were in part based on the trade in human energy and health as much as a trade in commodities and capital. While McMichael (2005b) has argued that food regimes constitute a 'vector of power', this article attempts to detail the multiple dimensions to that power.

The 1st food regime, the master nutrient and the imperial calorie

Although numerous European chemists made influential contributions, the modern phase of nutrition science is generally attributed to the physiological chemistry activities of German chemist von Liebig, and specifically to his identification in the middle 1800 s of:

the significance of protein as the chemical compound that accelerates the early growth of plants, animals and humans. ${ }^{1}$ Once protein was isolated and identified as the primary or master nutrient and so the nutritional expression of the dominant European ideology, [sic] food systems engineered to emphasise animal protein had the power to change the world, as they have done. (Cannon 2005, p. 702)

Isolation of the role of protein as a human growth accelerant took place at about the same time that the calorie was adopted as an effective metric for human energy requirements (Levenstein 1980). The quantification of human energy occurred when a calorimeter-previously used to measure the combustive energy of explosives and engines-was modified to measure individual energy expenditure under a range of highly controlled conditions. Wilbur Atwater-the 'Father of American Nutrition' and a scientist employed by the US Department of Agricultureadvocated the incorporation of the calorie within public policy from the 1880s onwards. His work strongly influenced US Foreign Policy, as the calorie was deemed to be an 'irrefutable and passionless yardstick' (Cullather 2007a, p. 34). In 1908, the US Secretary of State, an enthusiastic supporter of the calorimeter, introduced the subject of nutrition into 'tense negotiations' with Japan over spheres of influence in the Far East. According to Cullather, the calorie 'popularized a set of assumptions that allowed Americans to see food as an instrument of power, and to envisage a 'world food proble' amenable to political and scientific interventions (Cullather 2007a, p. 34).

Like von Liebig, Atwater shaped modern diets in multiple ways. He was a scientist who was emotionally engaged with his work, being particularly concerned about two American habits: a desire for expensive foods among the working classes (what he called a 'vanity') and eating beyond one's energy requirements. He placed dual emphasis upon thrift and nutritional knowledge, with a view to working class households replacing more expensive protein sources with any food containing the nutrients necessary for their tasks: he based this later piece of advice on science that showed that 'there was little perceptible difference in the way carbohydrates, fats, and most proteins of varying origins were metabolized by the human body (Levenstein 1980, p. 371).

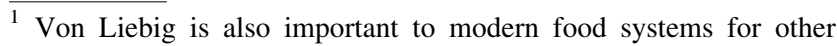
reasons: he invented nitrogen-based fertilisers and promoted sciencebased agriculture. Further, he derived a method for producing beef extract from carcasses: The Liebig Extract of Meat Company sold beef bouillon cubes (becoming the Oxo cube in 1899) as a cheap alternative to meat.
} 
However, despite his obsession with discovering the most efficient energy carriers he was opposed to sugar-based carbohydrates (especially in the form of sweets) believing them to be lacking in other nutritional virtues.

Atwater's and similar laboratory-based discoveries were well-received, as they were taking place against a backdrop of Engels' description of 'social murder' through starvation among the English working class. Heightened government fears of uprisings lent urgency to efforts to improve the poor's diets and living conditions.

In the 1890s, Atwater teamed up with a Democratic Party businessman in Boston to promote diets that would enable American workers to produce more than their German counterparts (Germany was the source of many nutrition science breakthroughs and the setting for Atwater's post-doctoral research). To this end, higher intakes of protein and fat, especially cheap cuts of meat and sources of fat (often in the form of fatty meat), were recommended. The two men believed that soups and stews would allow workers to become more productive and to improve their standard of living, without necessarily requiring wage rises to compensate for the food-energy consumed (Levenstein 1980, p. 372).

In the US, and in a context of an influx of many thousands of immigrant workers at the turn of the twentieth century, the idea that certain foods were more efficacious vehicles for human energy transmission gave rise to the 'scientific feeding' movement. Co-sponsored by land grant universities, the US Department of Agriculture and 'Progressive Era' reformers, the movement was devoted to spreading a middle class approach to the moral and wage earner economies (Mudry 2006). Referring to thousands of home economists administering the nutrition insights emerging from government agricultural and health laboratories, including Atwater's, Levenstein has suggested that:

Of all the great panoply of reformers seeking to change American life, a little group of turn-of-thecentury proponents of 'Scientific Eating' probably had more long-term impact on the daily lives of most Americans than any of their progressive colleagues... The battles of those who fought for pure food and drug legislation have attracted much more historical interest and controversy. But the more important growth of a vast establishment devoted to changing America's eating habits, rather than its food, has been ignored. (Levenstein 1980, p. 369)

The identification of animal foods as the master nutrient had considerable impact on meat's esteem beyond its role in the political economy of the US (Fiddes 1991). The calorie and protein as quantifiable sources of human energy exchanged for a quantifiable sum of money or money equivalent ('credit') was pivotal to the legitimacy of the 1st Food Regime.

The 2 nd food regime and the 'protective' vitamin

In terms of subsequent policies and corporate strategies, another highly influential nutrition science 'breakthrough' involved the idea of 'protective foods' following the 1912 application of the term 'vitamine' to encapsulate the life giving nature of amine compounds and other micro-nutrients (Cannon and Leitzmann 2005; Lawrence and Robertson 2007). The early twentieth century reframing of diseases, not as diseases of destitution but as diseases of vitamin deficiency, consolidated the influence of chemically based nutrition science (Cannon 2005); and provided food processing corporations with a new platform for profit-taking through food enrichment, or at the very least making rudimentary health claims about very ordinary, everyday foods.

Levenstein remains the best account of vitamania in the US from the 1920s onwards, and the role of American food processing companies in simultaneously de-nutrifying and re-nutrifying food supplies (Levenstein 1993). With the food shortages of World War 2, the British fortified margarine and flour with vitamins A, D and calcium, whilst in the US white bread was enriched with niacin, riboflavin, thiamine and iron: the same micronutrients removed in the previous 50 years through roller milling and bleaching of wheat (Lawrence and Worsley 2007). One quote encapsulates the consolidation of the embodied consequences of the nutritionalisation of the food system:

Taste and habit, long the sole arbiters of the dining table, seem overthrown', wrote one observer in 1930.

'Man, and perhaps more particularly woman, of the 1930 genus no longer eats what he likes in nonchalant abandon, fancy free. He eats what he thinks is good for him, on some scientific or pseudo-scientific hypothesis. (Levenstein 1993, p. 12)

About this time, Scottish chemist John Boyd Orr was embarking upon an ambitious research agenda: studying the energy expenditure of infantry recruits during training; the nutritional condition of sheep, cattle and East African 'natives'; and investigations of the dietary inadequacy of the 'labouring classes'. The Rowett Institute in Aberdeen Scotland, directed by Orr, mounted dietary studies to 'expose the gap between nutrient requirements and that consumed' and to indicate how the provision of 'protective foods' could contribute to human growth and health. This work along with a 'large scale demonstration of the nutritive value of milk for schoolchildren, done primarily to promote the health of children but secondarily to benefit the dairy industry, by promoting the increased consumption 
of milk, largely led to the adoption of the milk and mealsin-school schemes' (Cuthbertson 1972, p. 4).

Boyd Orr's 1936 report Food, Health and Income, which received enthusiastic support from the British government, entrenched a view that modern science was pivotal to the elimination of poverty, hunger and preventable disease (Cuthbertson 1972). He was made a Nobel laureate for his pursuit of peace through food security, and in 1945 became the first director-general of the FAO. From the FAO's own history, it appears that Boyd Orr had only limited success in anchoring the body's mandate to a principle that 'food is more than a trade commodity; it is an essential to life' (Food and Agriculture Organization 1985, p. 15).

Boyd Orr's emphasis on the universal access to protective foods gained some traction: but rather than their production being based in multi-domestic national systems and sustaining rural livelihoods, in most parts of the world system they were to be provided through food aid programs established according to The Guiding Lines and Principles of Surplus Disposal drawn up in 1954. Reflecting fear about a repeat of the 1930s food surpluses in Europe, the document enshrined the aim of 'avoiding both disruption to regular trade and discouragement of food production in recipient countries (FAO 1985, p. 19): an aim that was 'used almost daily by food aid programmes for more than 30 years as a code of international behaviour' (p. 16).

The Guiding Lines document is an excellent example of Friedmann's notion of the way in which 'explicit rules' mask the 'implicit rules' that guide food system political economies; while the reframing of aid to food surplus dumping is a fine example of a crisis in the making (Friedmann 2005). This discursive moment identifying the cynical culpability of wealthy agricultural producing states has been more recently joined by another which amplifies a similar tendency by the largest transnational corporations.

Food regimes crisis and the 'empty calorie'

What becomes clear from the previous two examples is that the imperial world order was facilitated by the international circulation of imperial calories and the even more imperial protein. The corporate world order fashioned out of the 2nd Food Regime was built upon the global trade in human health via a wide range of agricultural and processed products touting their vitamin content. However, with the success of the 2nd Food Regime adding cheap inputs, principally fats/oils and sugar sourced from the developing world, there has followed a rapid rise in diet-related disease. This particular crisis in nutrition is causing tensions between national governments and the processed food and food services sectors which can be major economic engines.
Despite the front covers of The New Statesman and other global business magazines announcing 'Food Crisis', there remains sufficient calorific energy for all six billion of the earth's inhabitants (Cohen et al. 2008, p. 14). The real problem is that the energy is not distributed justly: having receded during the 1960 s and 1970 s, the global mal-distribution of dietary energy has escalated since the $1980 \mathrm{~s}$ (McMichael 2005a, p. 711).

Even within affluent countries, growing numbers of people are going hungry (Cohen et al. 2008) and to sate their hunger are turning to cheap high energy dense foods, such as high grain 'mixed' dishes (e.g. Burritos) and cheese based dishes (e.g. pizza). A marked shift from visible to invisible fats is especially pronounced in the US, and is now claimed to be the major source of that country's obesity problem (Popkin et al. 2001).

Highlighting the lack of 'good nutrition' in the food system is as much a manifestation of nutritionalisation as is advocating particular nutrients. For instance, due to their relative absence of other beneficial nutrients the foods described above were termed 'empty calorie' foods by the Center for Science in the Public Interest in 1972. They are the very foods for which WHO/FAO (2004) found convincing evidence of an association with obesity. In the same year that the 'empty calorie' was named and shamed, physiologist John Yudkin, working at one of the UK's more prestigious nutrition departments, Queen Elizabeth College, published Pure, White and Deadly about the health problems associated with sugar consumption. It was an early example to use nutrition science as a basis for trenchant critique of industrial marketing and manipulation (Yudkin 1986). ${ }^{2}$ As Araghi (2003) would explain it, the empty calorie is an aspect of forced under-consumption for the working class. This class may now be portrayed as food over-consumers, but their overweight bodies are the result of insufficient incomes to consume fewer, less energydense foods (Drewnowski 2004).

Yudkin's critique was overly partial because the production of excessive calories and their class distribution is also the result of the earlier described nutrition science 'breakthroughs' receiving state backing (Crotty 1995; Cullather 2007b; Fiddes 1991; Levenstein 1996; Mudry 2006). It is now acknowledged, for example, that Atwater and colleagues' calculations regarding calorie and protein requirements were too high; and that US government recommendations for protein intake, implemented through the home economists program in the 1920s and 1930s, were twice as high as was necessary and actually harmful to

\footnotetext{
${ }^{2}$ In many respects Yudkin followed in the footsteps of Atwater in his belief that people's diets would only improve once they had been adequately educated about nutrition choices, and that this education should come from benevolent food industries enlightened by social scientifically trained nutritionists (Smith 1998).
} 
health (Levenstein 1980). ${ }^{3,4}$ Using the same scientific evidence, the FAO's announcement in the 1950s of a 'protein crisis' has been since reanalysed as a 'protein fiasco' (Cannon 2005); but in the intervening years has created a platform for food trade and aid programs that propelled European and US agricultural and political supremacy.

The socio-technical system responsible for the transition from the protein to vitamins to empty calories, and a subsequent nutrition crisis, was based on an interconnected web of firms, governments and pan-national organisations located in the US and 'old' Europe. With even more recent nutrition 'breakthroughs', described below, nutritionalisation is shifting the terrain away from the industrial chemistry of the old nutrition and the OECD towards proud culinary cultures which also happen to be major producers of nutritionally beneficial foods in Asia, Africa and South America. By reinterpreting the nutrition transition in food regime terms, further light can be shed on the intertwined fortunes of food regimes and nutrition value relations.

\section{The contested politics of nutritionalisation}

Today's protagonists to nutritionalisation constitute an ungovernable cabal ranging from 'health and wellness' transnational corporations and their lifescience 'front' organisations such as ILSI (Jacobson 2005), to antagonist global peasant, gastronomy and nutrition science movements and national governments concerned about the economic burden of dietary disease and culinary traditions. Prominent in naming what is wrong with the current state of the global and national food systems are several large global counter-movements. With their ecological and communal-orientations, the best documented are Via Campesina (McMichael 2005b) and Slow Food (Friedmann 2005). Civic agriculture is also enjoying a renewal. Its focus is on food sovereignty rather than nutrition security, although this is changing (Dixon et al. 2009).

Arguably the more potent critique of nutritionalisation has come from within the scientific community itself. With evidence that peasant type plant-based diets are healthier than the industrial diets advocated by nutrition scientists for much of the twentieth century (Jebb 2007; Cordain et al. 2005) has emerged one of the more intriguing

\footnotetext{
${ }^{3}$ High protein diets are bad for kidney function and rob the body of calcium. It is thus confusing to be encouraged to consume another protein rich food group, dairy, to protect against osteoporosis: a bonethinning condition that results from too little calcium absorption (DuPuis 2002, p. 116).

${ }^{4}$ The US government continues to recommend higher levels of protein than are advocated by the WHO (Lawrence and Worsley 2007).
}

movements to contest nutritionalisation. The New Nutrition Science Project (NNSp) is a joint effort of the International Union of Nutritional Sciences and the World Health Policy Forum. The NNSp first met in 2005 at the University centre in Giessen honouring von Liebig's work. According to two of the founders, the project arose through recognition that the biological basis for the discipline no longer served 'the long-term sustenance of life on earth and the happiness of humankind' (Cannon and Leitzmann 2006, p. 8). Operating from a nutrition ecology perspective (see Lang 2005), the group established what is called the Giessen Declaration which is being discussed in nutrition forums around the world. Resonant with Friedmann's understanding of 'crisis', the founding scientists argued that they were 'uncomfortably aware that the science is in crisis, in the Chinese sense of a time of danger and also of opportunity' (Cannon and Leitzman 2005, p. 677).

The project is taking the opportunity to enlarge the field's fundamental disciplinary base to include social and environmental sciences. Its advocacy of a pre-industrial ecological nutrition approach - akin to that being promoted by the Slow Food movement and Via Campesina-contrasts with the pursuit of the high-tech nutrified future being offered by the functional food, nano-tech and nutrigenomics sectors (Lawrence and Germov 2008; Scrinis 2007).

Nutritionalisation also appears to be losing its authority over some national governments. In Asia, there is incremental resistance to the nutrition science hegemony even from countries which have championed high technology food system advances. Events in Thailand are illustrative of shifts towards a more ecological approach, with the ninth National Social and Economic Plan (2002-2006) saying less about nutritional deficits than previous Plans and more about self-sufficiency in food production. References to 'the promotion of appropriate knowledge and technology by regarding local wisdom' appears as a counterpoint to a focus in earlier plans upon the government's promotion of nutritionally-led 'correct and appropriate eating behaviour' (Thailand Ministry of Public Health 2544). ${ }^{5}$

Even in Japan, the home of the functional food revolution thirty years ago, there appears to be a subtle turn away from a corporate controlled food system to a food system that is sympathetic to the environment and civic traditions. The government's desire to maintain a strong agricultural base, especially with regards to rice, and to defend its culinary traditions from international encroachments has seen the elaboration of food and nutrition policies which have mutually reinforcing health, economic and cultural aims.

Enacted in 2005, the Basic Law on Shokuiku, for example, is intended to tackle numerous concerns: diet-related

\footnotetext{
52544 is the Thai identification of the year 2001 .
} 
disease, poor eating behaviours-especially irregular meals, body image, food safety, over-dependence on imported foods, and loss of a traditional food culture through globalisation. Food producers and consumers are covered by the Law which provides both nutritional guidelines and unusual dietary practice advice like: 'take advantage of your dietary culture and local food products, while incorporating new and different dishes'; and 'establish a healthy rhythm by keeping regular hours for meals'. The Japanese Ministry of Agriculture, Forestry, and Fisheries is committed on principle at least to use Shokuiku to promote people's understanding of agriculture, forestry, fishery and food industry; and to perpetuate the older cooperative and place-based aspects of its food culture (see www.maff.go.jp/). Similarly, the South Korean government is promoting the health and cultural virtues of plant and rice based diets (Kim et al. 2000).

\section{Socio-technical system struggles over nutritionalisation: technical versus lifeworld rationality}

Food regime scholars with a critical eye on value relations at the world-scale have rarely ventured into the terrain of socio-technical systems theory, with its heavy emphasis on local cultural contexts. However, in spite of its universalising logic and substantial dependence on global capital and technical investments, nutritionalisation seems worthy of a socio-technical system interpretation. Showing a disregard for the century old view that the calorie, protein and vitamins constitute 'an irrefutable and passionless yardstick', the policy shifts described above support this contention. With the passing of the master nutrient has come the demise of a master narrative regarding nutrition.

In the terms of socio-technical systems, what we are witnessing is nutritionalisation as a cultural economy performance: 'it is located in human and non-human material practices' (Law 2002, p. 24), which vary depending on biosphere resources, the durability of national culinary cultures and the penetration of particular forms of epistemological enquiry. The non-human nutrient 'performs' when it changes in chemical character or amount, often due to human activities but also according to natural ecosystem discordance. Concrete examples include health damaging transfatty acids, not found in conventional agriculture, but present after manufacturing of vegetable oils (Cordain et al. 2005); and the lack of tolerance by cereal plants to pest diseases (Pingali 2006), especially under prolonged drying and water soak conditions. Human performance is to the fore through the establishment of codes, rules and exchange mechanisms to guide the valuation and incorporation of nutrient chemicals into daily life. The incalculable virtues and philosophies of nutrition have become 'qualities' scientifically embedded to erase, enhance or modify what is imagined to be desirable economically and culturally (Harvey et al. 2004).

Mintz's study (1985) of sugar cane across the ages exemplifies the shift. It reveals the prelude to the scientific elaboration of nutritionalisation, which lay in sugar's early lifeworld associations with health and wealth. Sugar's role in ancient medicine, both as a prescription for a wide range of ailments as well as providing an ingredient for many tonics, offered it legitimacy among the upper classes that predated sugar's esteem derived from rarity, expense and an exotic history: 'So useful was sugar in the medical practice of Europe from the thirteenth through the eighteenth centuries that the expression 'like an apothecary without sugar' came to mean a state of utter desperation or helplessness' (Mintz 1985, p. 101). Its status began to erode as medical practitioners identified a link to diabetes mellitus in the eighteenth century, and was hastened with pronouncements from new world nutrition scientists like Atwater, claiming it to be an inferior source of calorific energy. By the end of the nineteenth century, the upper class was replacing sugary foods with protein although they continued to figure prominently as a cheap energy hit to those unable to afford meat protein, providing workers with the lived experience of 'quick energy' (Mintz 1985, p. 147). We now know that owing to the human metabolic state, refined sugar consumption displaces more nutrientdense foods, even where these are widely available (Cordain et al. 2005, p. 348).

Another 'pre-scientific food' important to the emergent working class was dairy. Prior to the identification of vitamins and 'protective foods', milk was considered natural, complete and universal, and hence a 'perfect' food (DuPuis 2002). According to DuPuis, milk products were widely accepted because of their association with the life giving nature of milk for newborn animals and children. Non-liquid forms of dairy were a source of energy in the eighteenth and nineteenth centuries and continued to be esteemed as an alternative to the more expensive meat protein in Britain. Like sugar, consuming dairy products was prompted by its folkloric properties as much as its physical presence.

As nutrition epidemiology repeatedly testifies, coupling the esteem of foods originally eaten for survival and social reasons with commercial strategies can become a toxic brew. Mintz noted that workers' customary food practices, including their affinity for sugary confections and drinks, became 'solutions' to conditions over which they have no control' (Mintz 1996, p. 31). DuPuis' history underscores how the communal associations of milk's multiple benefits were enhanced through the activities from the mid-1800s onwards by corporations such as Nestle. With the vitamine 'discovery', dairy-based solids gained popularity across social groups, escalating with Vitamin D irradiation from 
1928 onwards. ${ }^{6}$ UK and US government support for milkin-schools programs begun in the 1930s, providing poor children access to nutrients considered essential for their development, was a major fillip for dairy industry constituencies in both countries.

Paraphrasing Habermas (1984), the social histories of sugar and dairy reveal a classic transition between two alternative forms of rationality: that of the technical sphere usurping the lifeworld. The former is consistent with an objectivist and instrumental view of social action. It is assumed to be value-neutral and in today's parlance is 'evidence-based', underpins efficiency of resource use and distribution and lays the basis for bureaucratic rule setting and adjudication. Lifeworld rationality, or the world of 'communicative' rationality, cannot be reduced to meansends calculations because it concerns customs, emotions, and other 'irrational' actions. This form of rationality can only be judged in terms of value commitments in given contexts.

As a result of cross-cultural studies of nutrition, Jelliffe proposed in the mid-1960s the existence of a 'world-wide' classification system that draws on the lifeworld and competes in the West with a dietary system based on core nutrients, secondary nutrients and peripheral nutrients. The system consists of: cultural superfoods (dominant staple foods), prestige foods, body-image foods (appropriate to birth signs as well as body balance beliefs like yin-yang), sympathetic magic foods (in Thailand these include 'wild foods' like frogs and mushrooms) and physiological group foods (foods appropriate to age, sex and physiologic conditions, like supplying quick energy) (see Fieldhouse for description of Jelliffe's contribution, 1995, p. 37). Those who continue to eat according to this classifactory system could be called 'culture eaters' in that they are not yet fully nutricentric citizens. While requiring further research, the clash of logics between the technical and the cultural will most likely contribute to shaping the emergence of any successor food regime.

\section{Contemporary nutrition value relations: the 'trade in health'}

At the same time that opponents to the corporate control of food systems like Via Campesina and Slow Food draw on a lifeworld rationality, there is a burgeoning 'trade in health' complex drawing on the technical rationality of nutrition science and food safety (Barling and Lang 2005; Blouin et al. 2009; Burch and Lawrence forthcoming). This complex comprises global production networks responsible

\footnotetext{
$\overline{{ }^{6} \text { Vitamin D }}$ is widely assumed even now to be a natural element of milk.
}

for both life sustaining commodities for undernourished populations as well as health promoting commodities for over-nourished populations. The networks responsible for the former continue as an outgrowth of the 2nd Food Regime while those in charge of the latter are harder to classify.

What increasingly unites the networks is a professional corps of hundreds of thousands of cultural intermediaries worldwide whose roles include regulating, auditing, researching and teaching nutritional value hierarchies. They are life sciences graduates whose numbers will increase with the application of human nutrition profiling to the creation of personalised diets: the ultimate in product differentiation scenarios (Scrinis 2007). Their universal language of nutrition science makes them an asset for corporations wanting to reach the burgeoning middle classes in countries where many people continue to consume 'medicinal' (physiological group foods in Jelliffe's terms) and 'magic' foods (See Seubsman et al. (2009) for an account of this situation in Thailand). To date, these populations have largely associated medicinal foods with bio-physical and spiritual environments but as these become built environments a dependence on industrially produced foods appears inevitable.

Due to one contemporary 'nutrition breakthrough', the trade in health complex is introducing Asian states, firms and cultural systems to the fore of the global food system. The latest wave of industrial foods, marketed as protective foods, is anti-oxidant-rich foods. Anti-oxidant research has been underway for more than a century, mainly in relation to its industrial uses in metals and rubber production. However in the last twenty years, food anti-oxidants or molecules that can reduce the oxidisation of human cells and hence prevent or slow down cancer cell growth and ageing have been a key subject for nutrition scientists and agricultural chemists (Wang et al. 1996; Cao et al. 1996; Trichopoulou and Vasilopoulou 2000). Vitamins A, C and E are classed as antioxidants, and their presence in fruits, vegetables and tea are likely to be responsible for catapulting these foods to the top of affluent people's shopping lists.

Controversy has erupted in medical circles as to whether a pharmaceutical source of anti-oxidants is as efficacious as agricultural (mainly horticulture and seafood) sources (Wald and Law 2003). With their low wage labour markets, vast tracts of horticulturally-productive lands and waters rich in seafood, Asian countries represent 'the (natural) anti-oxidant basket of the world'. 7 In the rush to identify the globalisation of diets as a Westernisation of

\footnotetext{
7 While these qualities also pertain to some South American and African states, these states do not have the added advantage of being identified in public health circles as practising healthy culinary cultures.
} 
diets, what is less observed is how the diets of Western cosmopolitans are becoming Occidentalised. Anglo-nation consumption of higher proportions of rice, fish and fruit, and lesser amounts of wheat products and red meat, represents the healthy flipside to the more widely described unhealthy aspects of the nutrition transition in Asia and elsewhere.

The transformation of Asian food systems away from rice production has been interpreted largely as the outcome of wealthy Asian urbanites demanding more Western diets of meat, wheat and dairy (Pingali 2006). This is correct, ${ }^{8}$ albeit unevenly practised depending on the country in question (Rae 1997). Equally, it is possible that declines in rice production and consumption in Asia have been driven by government policies to produce the 'next big thing' in Western nutrition. China, Thailand and Vietnam are using agricultural and aquaculture exports as part of their economic growth strategies (Pritchard and Burch 2003; Burch 2005). Thailand, for example, not only claims the title 'Detroit of the East' but also 'Kitchen to the World'. In these countries small farmers are commercialised to produce the horticultural and seafood diversity being demanded by OECD country consumers, for whom domestic production is either depleted through over-production or for whom what were sufficient levels of consumption twenty years ago is no longer enough as they seek protection from diseases of modernity and ageing.

While debates rage regarding the best source of antioxidants, bio-technology, pharmaceutical and agri-food companies based mainly in Europe, the US and Japan are devoting large sums of $R \& D$ money to bring onto the market so-called 'functional foods', including those claiming anti-oxidant benefits (Lawrence and Germov 2008). The importance of anti-oxidants to commerce is that as yet they have not been found to pose toxicity risks, and they are highly performative. For example, among different strawberry cultivars there can be a host of different antioxidant values, and hence potential to create enormous product differentiation. Moreover, while strawberry processing reduces antioxidant activity, the waste by-product is being promoted as a source of industrially produced nutraceuticals (Aaby et al. 2005, p. 4032).

Despite my earlier argument about nutritionalisation losing some authority over Asian governments, there is a two-way trade in nutrition taking place that requires further elaboration. The enduring influence of nutrition science over dietary regimes is evidenced by its capacity to insinuate 'foreign foods' with no links to culinary history. The

\footnotetext{
8 Across Asia, Pingali (2006) estimates that temperate zone commodities like beef, dairy products, wheat and vegetables such as potatoes, have increased in consumption by a factor of thirteen between the early 1960s and late 1990s. They are responsible for turning Asia into a net importer of foods (Fold and Pritchard 2005).
}

trade in dairy to Asia, one way for Western nations to reclaim Asia's export earnings from anti-oxidant rich foods, is a good example.

Contrary to the universal palate for sugar, tolerances for dairy vary markedly and do not extend to most Asian populations. However, data show that some of the most dramatic increases in dairy consumption have taken place among these populations, due to several factors: urban consumers desiring Western commodities; the spread of Western food retail formats pushing cheese-based meals and other novel products; and trade liberalisation being driven by the WTO (Beghin 2006; Dong 2006). Governments concerned about micro-nutrient deficiencies have also contributed to this demand. Until the 1980s, for example, Thais consumed few dairy products preferring instead to cook with, and to drink, coconut milk which came their way via Arabic and Indian traders many centuries earlier (Seubsman et al. 2009). However, this preference was challenged when the country's National Food and Nutrition Plan (1992-1996) identified 'protein energy malnutrition'9 as a major problem. One result, auspiced under the accompanying National Economic and Social Plan, was the School Lunch Fund Act to provide primary school children with at least one nutritionally balanced meal a day, including provision of free milk (http://www.fao.org/documents/ Thailand). This type of initiative, mirroring that of Western governments 60 years before, is also present in Japan and South Korea (Dong 2006).

Unlike the North-South transfers of earlier regimes, the dairy to-South-East Asia case highlights a less straightforward arrangement, with Australia, New Zealand and several South American states (Argentina, Brazil) being the primary exporters. ${ }^{10}$ Typical of earlier 'breakthroughs', there will be marked inequalities as to which sub-populations can critically assimilate the science and access antioxidants, which are being commodified by several complexes: the horticulture and fishing complexes and the biotech complex. For Asian, African and South American countries that are exporting these 'naturally' occurring anti-oxidants and pricing them out of the reach of local producer communities, genetically engineered functional food crops like Golden Rice containing vitamin A are assuming importance for food security reasons (Dawe et al. 2002; Zimmermann and Qaim 2004). As functional healthpromoting foods become more acceptable to consumers in rich and poor countries alike, they will strengthen corporate

\footnotetext{
${ }^{9}$ In the fourth plan (1977-1981), the protein was to take the form of mung bean and soy bean. Thailand has not followed the typical path of the nutrition transition with increases in red meat consumption (Rae 1997).

${ }^{10}$ This situation does not negate the transfer of anti-oxidant rich foods from South to North: from Africa to Europe, and from South America to Europe and North America.
} 
capital's capacity to leverage influence over governments experiencing fiscal crises in relation to their health care systems due to diet-related diseases.

A decade ago, Pritchard (1998) used the Australian dairy complex to investigate a putative 3rd Food Regime; but found domestic firm-level limitations to the incursions of the requisite global capital to coordinate food system relations. Despite subsequent deregulatory events making it easier for global operators, as well as the entry of foreign supermarket chains, I would argue that future food relations will not be based on the activities of any particular global commodity production network but will be based on broader processes of social ordering, whether financialisation, nutritionalisation or ecology. The articles in this Issue bear out this contention.

In regard to nutritionalisation, the potency of social movements wedded to a lifeworld rationality problematising capitalist food relations and the technical rationality underpinning the trade in health sector becomes clear (see also Friedmann 2005). Moreover, while the New Nutrition Science project adopts technical rationality arguments, its commitment to an ecological ontology insinuates lifeworld rationality along the way. This same ontology is manifest in the daily activities of culture eating sub-populations determined to cling to foodways which privilege history, locality and cultural identity. For these groups, the trade in nutritional health is not only alien but mono-dimensional with its disregard for producer livelihoods, cuisine and pleasure in food.

\section{Conclusion}

The food regime analysis of the nutrition transition outlined in this article confirms the ongoing utility of the approach for attributing the distinctive contributions of interlinked social processes to the reproduction of power relations. Specifically, it has helped me to reveal how the nutritionalisation of national and international food systems has continued as an unbroken socio-technical and knowledge revolution. The capacity to quantify human energy introduced 'scientific eating' into public policy and legitimised the agri-food import-export complexes that underpinned the 1st and 2nd Food Regimes. For the first sixty years or so, nutrition science contributed to the stability of an emergent food order. The imperial calorie was fostered by governments keen to exercise political influence over domestic labour markets and over colonised governments, while the protective vitamin masked the dumping of inferior processed foods. More recently, these empty calorie foods have provided the basis for the contemporary food crisis; which in turn is laying the ground for the next capital accumulation platform: the trade in nutritional health.
Because of associations with the field of medicine, although industrial chemistry is more appropriate, nutrition science continues to offer a moral economy cloak missing from the 'free trade of food', which is meeting stiff resistance from a broad church of national governments, social movements and food consumers. For this reason, nutrition value relations are likely to underpin global food system dynamics into the future. Any successor 3rd Food Regime will comprise those elements which bring order to the 'trade-in-health' sector while catering to 'culture eaters' for whom nutrition value relations are secondary to more communally and ecologically oriented relations. This dynamic is present within wealthier Asian states which are central to the trade-in-health dynamics while acting to protect their own customary dietary practices.

What becomes apparent through weaving this recursive narrative of value relations and temporo-spatial food orderings is how well the food regimes approach is suited to the multiple planes demanded for the study of ecological dynamics. Its trump card lies in its theoretically grounded series of interlinked concepts and therefore a capacity to deal simultaneously with the interrelationships between political order and ontological and material crisis.

Acknowledgements Hugh Campbell and Phillip McMichael played highly significant roles in the shaping of this argument, and I also acknowledge an early contribution by Farshad Araghi. I am also grateful to P. Suttinan of the Sukothai Thammathirat Open University for translating the contents of the Thai government's Nutrition Plans.

\section{References}

Aaby, K., G. Skrede, and R. Wrolstad. 2005. Phenolic composition of antioxidant activities in flesh and achenes of strawberries (Fragaria ananassa). Journal of Agriculture and Food Chemistry 53: 4032-4040.

Adams, T. 2007. 'A troubled relationship to food': Betsy Lerner's food and loathing: A lament. Paper presented to the agriculture, human values and food conference, 30 May-3 June 3, in Victoria, BC.

Araghi, F. 2003. Food regimes and the production of value: Some methodological issues. The Journal of Peasant Studies 30 (2): 41-70.

Barling, D., and T. Lang. 2005. Trading on health: Cross-continental production and consumption tensions and the governance of international food standards. In Cross-continental food chains, ed. N. Fold and B. Pritchard, 39-51. London: Routledge.

Beghin, J. 2006. Evolving dairy markets in Asia: Recent findings and implications. Food Policy 31: 195-200.

Belasco, W. 1993. Appetite for change: How the counter culture took on the food industry, 316. Ithaca: Cornell University Press.

Blouin, C., M. Chopra, and R. van der Hoeven. 2009. Trade and social determinants of health. The Lancet: 1-6. doi:10.1016/ S0140-6736(08)61777-8.

Burch, D. 2005. Production, consumption and trade in poultry: Corporate linkages in North-South supply chains. In Crosscontinental food chains, ed. N. Fold and B. Pritchard, 166-178. London: Routledge. 
Burch, D., and G. Lawrence (forthcoming). The 'Wellness' phenomenon: Implications for global agri-food systems. In Food security, nutrition and sustainability: New challenges, future options, ed. K. Lyons, G. Lawrence, and T. Wallington. London: Earthscan.

Cannon, G. 2005. The rise and fall of dietetics and of nutrition science, 4000 BCE-2000 CE. Public Health Nutrition 8 (6A): 701-705.

Cannon, G., and C. Leitzmann. 2005. The new nutrition science. Public Health Nutrition 8 (6A): 673-694.

Cannon, G., and C. Leitzmann. 2006. The New Nutrition Science project. Scandinavian Journal of Food and Nutrition 50 (1): 5-12.

Cao, G., E. Sofic, and R. Prior. 1996. Antioxidant capacity of tea and common vegetables. Journal of Agricultural and Food Chemistry 44: 3426-3431.

Carlsson-Kanyama, A., M. Ekstrom, and H. Shanahan. 2003. Food and life cycle energy inputs: Consequences of diet and ways to increase efficiency. Ecological Economics 44: 293-307.

Cohen, M., C. Tirado, N. Aberman, and B. Thompson. 2008. Impact of climate change and bioenergy on nutrition. Washington, DC: The International Food Policy Research Institute and Food and Agriculture Organization of the United Nations.

Cordain, L., B. Eaton, A. Sebastian, N. Mann, S. Lindeberg, B. Watkins, J. O'Keefe, and J. Brand-Miller. 2005. Origins and evolution of the Western diet: Health implications for the 21st century. American Journal of Clinical Nutrition 81: 341-354.

Coveney, J. 2006. Food, morals and meaning, 2nd ed. London: Routledge.

Crotty, P. 1995. Good nutrition? Fact and fashion in dietary advice. Sydney: Allen \& Unwin.

Cullather, N. 2007a. American Pie: The imperialism of the calorie. History Today 57 (2): 34-40.

Cullather, N. 2007b. The foreign policy of the calorie. American Historical Review 112: 337-364.

Cuthbertson, D. 1972. Obituary Notice. Lord Boyd Orr. British Journal of Nutrition 27 (1): 1-5.

Dawe, D., R. Robertson, and L. Unnevehr. 2002. Golden rice: What role could it play in alleviation of vitamin A deficiency? Food Policy 27: 541-560.

Dixon, J. 2002. The changing chicken: Chooks, cooks and culinary culture. Sydney: UNSW Press.

Dixon, J., and C. Banwell. 2004. Reembedding trust: Unravelling the construction of modern diets. Critical Public Health 14: 117131.

Dixon, J., K. Donati, L. Pike, and L. Hattersley. 2009. Functional foods and urban agriculture: Two responses to climate change related food insecurity. NSW Public Health Bulletin 20 (1-2): $14-18$.

Dong, F. 2006. The outlook for Asian dairy markets: The role of demographics, income, and prices. Food Policy 31: 260-271.

Drewnowski, A. 2004. Obesity and the food environment: Dietary energy density and diet costs. American Journal of Preventive Medicine 27 (3, Supplement 1): 154-162.

DuPuis, M. 2002. Nature's perfect food. New York: New York University Press.

Elinder, L. 2005. Obesity, hunger and agriculture: The damaging role of subsidies. British Medical Journal 331: 1333-1336.

FAO Corporate Document Reposition. 2007. Thailand. http://www.fao.org/documents/Thailand. Accessed Feb 2007.

Fiddes, N. 1991. Meat: A natural symbol. London: Routledge.

Fieldhouse, P. 1995. Food and nutrition. Customs and culture. London: Chapman \& Hall.

Fischler, C. 1993. A nutritional cacophany or the crisis of food selection in affluent societies. In For a better nutrition in the 21 st century, ed. P. Leathwood, M. Horisberger, and W. James, 5765. New York, NY: Vevey/Raven Press.
Fogel, R. 2004. The escape from hunger and premature death. Cambridge, UK: Cambridge University Press.

Fold, N., and B. Pritchard. 2005. Introduction. In Cross-continental food chains, ed. N. Fold and B. Pritchard, 1-22. London: Routledge.

Food and Agriculture Organization of the United Nations. 1985. FAO the first 40 years: $1945-85,155$ pp. Rome: Food and Agriculture Organization of the United Nations.

Friedmann, H. 2005. From colonialism to green capitalism: Social movements and emergence of food regimes. In New directions in the sociology of global development, ed. F. Buttel and P. McMichael, 227-264. Oxford: Elsevier.

Friedmann, H., and P. McMichael. 1989. Agriculture and the state system. Sociologia Ruralis 39 (2): 93-117.

Guthman, J., and M. DuPuis. 2006. Embodying neoliberalism: Economy, culture and the politics of fat. Environment and Planning D: Society and Space 24: 427-448.

Habermas, J. 1984. The theory of communicative action, vol. 1. London: Heinemann.

Harvey, M., A. McMeekin, and A. Warde, eds. 2004. Qualities of food. Manchester: Manchester University Press.

Hawkes, C. 2006. Uneven dietary development: Linking the policies and processes of globalization with the nutrition transition, obesity and diet-related chronic diseases. Globalization and Health 2 (4): 1-18.

Heasman, M., and J. Mellentin. 2001. The functional food revolution: Healthy people, healthy profits. London: Earthscan.

Jacobson, M. 2005. Lifting the veil of secrecy from industry funding of nonprofit health organizations. International Journal of Occupational Environmental Health 11: 349-355.

Japanese Ministry of Agriculture, Forestry, and Fisheries. 2008. What is 'Shokuiku (Food Education)'? http://www.maff.go.jp/. Accessed 1 June 2008.

Jebb, S. 2007. Dietary determinants of obesity. Obesity Reviews 8: 93-97.

Kim, S., S. Moon, and B. Popkin. 2000. The nutrition transition in South Korea. American Journal of Clinical Nutrition 71: 44-53.

Lang, T. 2005. Food control or food democracy? Re-engaging nutrition with society and the environment. Public Health Nutrition 8 (6A): 730-737.

Law, J. 2002. Economics as interference. In Cultural economy, ed. P. du Gay and M. Pryke, 21-38. London: Sage.

Lawrence, M., and J. Germov. 2008. Functional foods and public health nutrition policy. In A sociology of food and nutrition, ed. J. Germov and L. Williams, 147-175. South Melbourne: Oxford University Press.

Lawrence, M., and A. Robertson. 2007. Reference standards and guidelines. In Public health nutrition: From principles to practice, ed. M. Lawrence and T. Worsley, 39-70. Crows Nest, Australia: Allen \& Unwin.

Lawrence, M., and T. Worsley. 2007. Public health nutrition: From principles to practice. Crows Nest, Australia: Allen \& Unwin.

Leopold, M. 1985. The transnational food companies and their global strategies. International Journal of Social Science 37 (3): 315330.

Levenstein, H. 1980. The New England Kitchen and the origins of Modern American eating habits. American Quarterly 32 (4): 369-386.

Levenstein, H. 1993. Paradox of plenty. A social history of eating in modern America. New York: Oxford University Press.

Levenstein, H. 1996. The politics of nutrition in North America. Neuroscience and Behavioural Reviews 20 (1): 75-78.

McKeown, T. 1979. The role of medicine. Oxford: Basil Blackwell.

McMichael, A. 2005a. Integrating nutrition with ecology: Balancing the health of humans and biosphere. Public Health Nutrition 8 (6A): 706-715. 
McMichael, P. 2005b. Global development and the corporate food regime. In New directions in the sociology of global development, ed. F. Buttel and P. McMichael, 265-299. Oxford: Elsevier.

McMichael, P. 1996. Development and social change. Thousand Oaks, California: Pine Forge Press.

McMichael, A., J. Powles, C. Butler, and R. Uauy. 2007. Food, livestock production, energy, climate change, and health. The Lancet 370 (9594): 1253-1263.

Mendez, M., and B. Popkin. 2004. Globalization, urbanization and nutritional change in the developing world. Journal of Agricultural and Development Economics 1 (2): 220-241.

Mintz, S. 1985. Sweetness and power. New York: Penguin.

Mintz, S. 1996. Tasting food, tasting freedom. Boston: Beacon Books.

Mudry, J. 2006. Quantifying an American eater: Early USDA food guidance, and a language of numbers. Food, Culture and Society 9 (1): 49-67.

Nestle, M. 2002. Food politics. Berkeley: University of California Press.

OECD. 2008. Promoting sustainable consumption: Good practice in OECD countries. Paris: Organisation for Economic Co-operation and Development.

Oresund Food Network and Oresund Environment Academy. 2008. Climate change and the food industry: Climate labelling for food products; Potential limitations. Kobenhavn S: Oresund Food Network and Oresund Environment Academy.

Pingali, P. 2006. Westernization of Asian diets and the transformation of food systems: Implications for research and policy. Food Policy 32: 281-298.

Popkin, B. 1999. Urbanization, lifestyle changes and the nutrition transition. World Development 27 (11): 1905-1916.

Popkin, B. 2003. The nutrition transition in the developing world. Development Policy Review 21 (5-6): 581-597.

Popkin, B., A. Siega-Riz, P. Haines, and L. Johns. 2001. Where's the fat? Trends in US diets 1965-1996. Preventive Medicine 32: 245-254.

Porter, D. 1999. Health, civilization and the state. A history of public health from ancient to modern times. London: Routledge.

Pritchard, W. 1998. The emerging contours of the third food regime: Evidence from Australian dairy and wheat sectors. Economic Geography 74: 64-74.

Pritchard, B., and D. Burch. 2003. Agri-food globalization in perspective: International restructuring in the processed tomato sector. Aldershot: Gower.

Rae, A. 1997. Changing food consumption patterns in Easy Asia: Implications of the trend towards livestock products. Agribusiness 13: 33-44.

Rozin, P. 2005. The meaning of food in our lives: A cross-cultural perspective on eating and well-being. Journal of Nutrition Education and Behavior 37 (Suppl 2): S107-S112.

Scrinis, G. 2007. The emerging nano-corporate paradigm: Nanotechnology and the transformation of nature, food and agri-food systems. International Journal of Sociology of Food and Agriculture 15 (2): 22-44.

Scrinis, G. 2008. Functional foods, functionally marketed foods? A critique of, and alternatives to, the category of 'functional foods'. Public Health Nutrition 11 (5): 541-545.
Seubsman, S.-A., J. Dixon, P. Suttinan, and C. Banwell. 2009. Thai meals. In Meals in science and practice: Interdisciplinary research and business applications, ed. H. Meiselman, 413-451. Oxford: Woodhead Publishing.

Smith, D. 1998. The discourse of scientific knowledge of nutrition and dietary change in the twentieth century. In The nation's diet, ed. A. Murcott, 311-331. London: Longman.

Steckel, R. 2001. Industrialization and health in historical perspective. In Poverty, inequality, and health, ed. D. Leon and G. Walt, 3757. Oxford: Oxford University Press.

Steinfeld, H., P. Gerber, T. Wassenaar, V. Castel, M. Rosales, and C. de Haan. 2006. Livestock's long shadow: Environmental issues and options. Rome, Italy: Food and Agriculture Organization of the United Nations.

Thailand Ministry of Public Health. 2544. Nutrition Plan in the 9th National Economic and Social Development Plan (2545-2549), 29-47 (trans: P. Suttinan, 2007). Thailand: Sukhothai Thammathirat Open University.

Trichopoulou, A., and E. Vasilopoulou. 2000. Mediterranean diet and longevity. British Journal of Nutrition 84: S205-S209.

Ulijaszek, S. 2002. Human eating behaviour in an evolutionary ecological context. Proceedings of the Nutrition Society 61: 517526.

Wald, N., and M. Law. 2003. A strategy to reduce cardiovascular disease by more than $80 \%$. BMJ 326 (7404): 1419.

Wang, H., G. Cao, and R. Prior. 1996. Total antioxidant capacity of fruits. Journal of Agricultural and Food Chemistry 44: 701-705.

Weis, T. 2007. The global food economy: The battle for the future of farming. London: Zed Books.

WHO. 2002. World health report. Reducing risks, promoting healthy life. Geneva: World Health Organisation.

WHO/FAO. 2004. Global strategy on diet, physical activity and health. Geneva: World Health Organization.

World Bank. 2006. Repositioning nutrition as central to development: A strategy for large-scale action. Washington, DC: The International Bank for Reconstruction and Development/The World Bank.

Yudkin, J. 1986. Pure, white and deadly, 2nd ed. London: Penguin. Zimmermann, R., and M. Qaim. 2004. Potential health benefits of Golden Rice: A Philippine case study. Food Policy 29: 147-168.

\section{Author Biography}

Jane Dixon PhD, is a Fellow at the National Centre for Epidemiology and Population Health, Australian National University. She is involved in three streams of research: associations between food system transitions, culinary cultures and chronic disease; the social and health impacts of supermarket chain restructuring of food systems; and the performance of diverse food economies under climate change. Her research takes place in Australia and Thailand. 